\title{
Environmental impact of seawater desalination plants: case study in Algeria
}

\author{
Kamal Mohammedi ${ }^{1}$, Anissa Talamali ${ }^{1}$, Youcef Smaili ${ }^{1}$, Imane Saadoun $^{1}$, Aomar Ait-Aider ${ }^{2}$ \\ ${ }^{1}$ MESOteam, LEMI, M. Bougara University Boumerdes, Algeria \\ ${ }^{2}$ M. Mammeri University, Tizi-Ouzou, Algeria
}

Email address:

mohammedik@yahoo.com(K. Mohammedi)

\section{To cite this article:}

Kamal Mohammedi, Anissa Talamali, Youcef Smaili, Imane Saadoun, Aomar Ait-Aider. Environmental Impact of Seawater Desalination Plants: Case Study in Algeria. American Journal of Environmental Protection. Vol. 2, No. 6, 2013, pp. 141-148. doi: $10.11648 /$ j.ajep.20130206.14

\begin{abstract}
This paper focuses on Environmental impacts associated with concentrated brine rejection in the Mediterranean arising from seawater desalination plants in Algeria. We present a case study on the environmental impacts of Cape Djinet Power/MSF seawater desalination plant. These impacts are mainly due to brine discharge but also to a lesser degree the chemicals used in the cleaning of various modules, thermal pollution, etc.. We performed the measurement of four parameters (temperature, $\mathrm{pH}$, salinity and conductivity), exergy analysis and numerical simulation to visualize the effects of rejection. Measurements of temperature and $\mathrm{pH}$ are compliant Algerian liquid discharges indicated in the legislative knowing that there are no limits imposed on the conductivity and salinity. Global results show no effect while there is a local impact due to the relatively small size of the resort of Cape Djinet $\left(4 \times 500 \mathrm{~m}^{3} /\right.$ day $)$. CFD simulation was used to visualize the effect of brine discharge in the sea.
\end{abstract}

Keywords: Seawater, Desalination, MSF, CFD, Performances, Exergy Analysis

\section{Introduction}

Algeria experienced during the nineties a severe drought with a critical shortage of drinking water threatening even the industrial and irrigation activities [N. Boutarfa2004, A. Sadi2004]. Water shortages, whether cyclical or structural, are a fact known to worsen in the future, while nearly one billion people still lack access to safe drinking water and demand on resources exceeds the renewable supply. In the EUMENA, irregular and declining rainfall situation combined to the rapidly increasing water demand for irrigation, industry and the population incompressible needs is of great concern to policy makers constrained to mobilize more groundwater and surface resources and use intensive water desalination. Desalination is nevertheless a high energy consumption process contributing to GHGs emissions and a potential threat to the environment by inducing damage to the marine environment. The research devoted to the assessment of impacts of desalination on the marine ecosystems are so far limited [S. Latteman2003,2010 , Y. Tamim2005, C. Santana2005]. More than 15,000 desalination plants around the world lead to a substantial production of brine from brackish and seawater desalination, while a half of intake massflowrateis rejected. The discarded brine has an impact on marine environment as its concentration is about twice the intake seawater and include Pre- and post-treatment chemicals. While energy recovery through pressure exchangers or Pelton turbines is widely used, production of salt and additional water from the rejected brine is a part of the solution but is economically not often feasible. In this last case, renewable energy can be used for brine evaporation in order to lower the costs in the context of rapidly growing demand for high purity vacuum salt. For thermal processes, mainly multistage flash (MSF), reducing thermal pollution is a big issue while seawater temperature, salinity, water currents and turbidity increase [I.S. Al-Mutaz, 2012].

Algeria experience in desalination started during the sixties with the building of multi-stage flash distillation (MSF) and mechanical vapor compression (MVC) plants in order to supply with water the growing oil and steel industries [G. Bravo2004]. Forty four (44) MSF seawater desalination plants totalizing a capacity of $111.000 \mathrm{~m}^{3} /$ day are supplying the petrochemical process industry and power generation plants (e.g. most of the Algerian steam power plants are fed with distillate water from small scale 
MSF desalination plants). The high purity of the distillate obtained from MSF has imposed this reliable and safe process compared to $\mathrm{RO}$ which is mainly used in Algeria for fresh water production. While in Gulf Cooperation Council (GCC) area, MSF is the main water desalination process for either drinking and industrial purposes applications. Most of the thermal desalination capacities installed in the world during the last decade are mainly concentrated in this area where energy is, for instance, affordable at a very low cost. In desalination processes, the levelised water cost (LWC) is mainly dependant on the energy cost. During the last decade distillation processes energy consumption have been lowered and many investigations based on exergy analysis [HouShaobo 2008, A.S. Nafey2006, A.A. Mabrouk2007, N. Scenna2008, A. Sung Joon2008, G. Cali2008, Y. Cerci2003, N. Kahraman2005] and systems analysis environments [M.S. Tanvir2008, A.S. Nafey2006, A.A. Mabrouk2007, J. Rheinländer2003, E. Perz2006, K.Mohammedi2010, D.Boudieb 2012] were conducted for performances and diagnosis improvement. A new design for an MSF-MVC desalination process was investigated by A.A. Mabrouk and al. [A.A. Mabrouk2007] under different operating conditions using a developed Design and Simulation software. A thermo- economic analysis based on energy/exergy balances was performed. The effect of the number of stages in the heat recovery section was studied. The results show that the low unit product cost was obtained at 20 stages. The performance ratio of the proposed MSF-MVC system was 2.4 times the performance ratio of the conventional MSF process. The heat transfer area of the MSF-MVC system was $57 \%$ higher than that of MSF while the exergy efficiency of the MSF-MVC system was $67 \%$ higher. The thermo-economic analysis results show that the unit product cost of MSF-
MVC, under the specified conditions, was calculated by 2.0 $\$ / \mathrm{m}^{3}$; this value is $25 \%$ less than that of the conventional MSF process.

\section{MSF Desalination Plant Case Study (Cape Djinet, Algeria)}

The Cape Djinet MSF desalination plant is located 70 $\mathrm{km}$ west of Algiers (Algeria), on the Mediterranean coast. The nominal distilled water production is $500 \mathrm{~m}^{3} /$ day from four small scale MSF desalination plants to supply a 700 MW steam power cycle with distilled water. A simplified flow diagram of the analysed MSF plant is shown in Figure 1. The plant consists of three subsystems: The MSF plant with $15+3$ flashing stages, the power generation section and the pre/post treatment sections.

Seawater enters the plant at (1) at a rate of $66.38 \mathrm{~kg} / \mathrm{s}$. It serves as a coolant in the later flashing stages (seawater temperature rises from 308 to $316.3 \mathrm{~K}$ ), and is discharged back to the sea (16), while $14.44 \mathrm{~kg} / \mathrm{s}$ is supplied into the flashing chamber after it is treated with chemicals. The mixture in the flashing unit at $316.3 \mathrm{~K}$ with a salinity of $64.828 \mathrm{~g} / 1$ is pumped back into a cooling line through the flashing chamber, and its temperature rises to $358 \mathrm{~K}$ as it cools and condenses the water steam in the flashing stages. The saline water is vaporized in a heat exchanger. The steam is condensed and the distillate water is collected at an incoming massflowrate of $5.78 \mathrm{~kg} / \mathrm{s}$ while waste brine is partially rejected at a rate of $8.61 \mathrm{~kg} / \mathrm{s}$ and a salinity of $70.093 \mathrm{~g} / \mathrm{l}$. The brine is flashed to lower pressures in the successive stages.

Main parameters and thermodynamic properties at each point of the process cycle are summarized in Table 1 and Table 2.

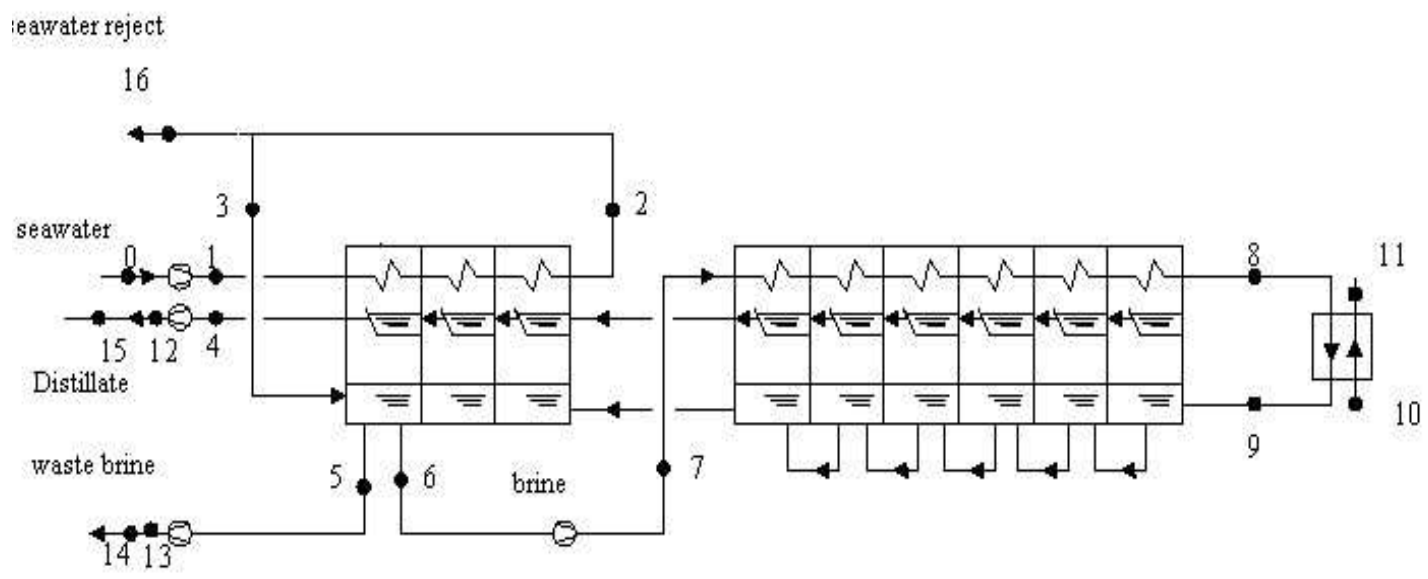

Fig.1: Cape-Djinet MSF plant simplified flowsheet process

\section{Energy and Exergy Analyses}

From the energy balance and after computing the enthalpy and entropy flowrates values of each component [K. Mohammedi, 2008], we can estimate the exergy for salt/water mixture for any state of the process cycle using the following relation:

$$
\mathrm{Ex}_{\mathrm{i}}=\mathrm{H}-\mathrm{H}_{0}-\mathrm{T}_{0}\left(\mathrm{~S}-\mathrm{S}_{0}\right)
$$

The exergy balance is given by the following relation: 


$$
\begin{gathered}
\sum\left(1-\mathrm{T}_{\mathrm{a}} / \mathrm{Tj}\right) \cdot \mathrm{Q}_{\mathrm{j}}-\sum \mathrm{W}_{\mathrm{i}}+\sum \mathrm{m}_{\text {inn }} \cdot\left(\mathrm{h}_{\mathrm{in}}-\mathrm{T}_{\mathrm{a}} \mathrm{s}_{\mathrm{in}}\right)-\sum \mathrm{m}_{\text {out }}\left(\mathrm{h}_{\text {out }}-\mathrm{T}_{\mathrm{a}} \cdot \mathrm{s}_{\text {out }}\right)- \\
\mathrm{T}_{\mathrm{a}} \mathrm{S}_{\text {crea }}=0
\end{gathered}
$$

Salinity of seawater is $39.4 \mathrm{~g} / \mathrm{l}$, corresponding to salt and water mass fractions $\mathrm{m} \mathrm{f}_{\mathrm{s}}=0.0394$ and $\mathrm{m} \mathrm{f}_{\mathrm{w}}=0.9606$ respectively. The mass fractions of salt and water are obtained from the following relations:

$$
\mathrm{M} \mathrm{f}_{\mathrm{s}}=\mathrm{m}^{\mathrm{s}} / \mathrm{m}_{\mathrm{m}} \text { and } \mathrm{m} \mathrm{f}_{\mathrm{w}}=\mathrm{m}^{\mathrm{w}} / \mathrm{m}_{\mathrm{m}}
$$

As we have $m_{m}=m_{w}+m_{s}$ then,

$$
m f_{w}+m f_{s}=1
$$

Finally, we obtain the following results for the salt and water mass fractions: $m f_{s}=0.0394 \mathrm{and} m f_{w}=0.9606$.

Assuming an ideal solution for the seawater, the specific enthalpy and entropy of the water/salt mixture are calculated using the following relations:

$$
\begin{aligned}
& \mathrm{h}=\mathrm{mf}_{\mathrm{s}} \cdot \mathrm{h}_{\mathrm{s}}+\mathrm{mf}_{\mathrm{w}} \cdot \mathrm{h}_{\mathrm{w}} \\
& \mathrm{s}=\mathrm{mf}_{\mathrm{s}} \cdot \mathrm{s}_{\mathrm{s}}+\mathrm{mf}_{\mathrm{w}} \cdot \mathrm{s}_{\mathrm{w}}
\end{aligned}
$$

The ambient conditions at intake point are: $\mathrm{T}_{0}=288 \mathrm{~K}$, $\mathrm{P}_{0}=1.013$ bars, $\mathrm{Sal}_{0}=39.4 \mathrm{~g} / 1$. The specific heat of salt is $\mathrm{Cp}_{\mathrm{s}}=0.8368 \mathrm{k} \mathrm{J} / \mathrm{kg}$. The enthalpy and entropy values at temperature $\mathrm{T}_{0}$ are $\mathrm{h}_{\mathrm{s} 0}=16.736 \mathrm{~kJ} / \mathrm{kg}$ and $\mathrm{s}_{\mathrm{s} 0}=0.05913 \mathrm{~kJ} / \mathrm{kg}$ respectively while for a temperature $\mathrm{T}$ the relations (7) and (8) are used:

$$
h_{s}=h_{s 0}+C p_{s} \cdot\left(T-T_{0}\right)
$$

and

\begin{tabular}{|c|c|c|c|c|c|c|}
\hline \multirow{2}{*}{$\begin{array}{l}\text { states } \\
0\end{array}$} & \multirow{2}{*}{$\begin{array}{l}\mathbf{T}(\mathbf{K}) \\
293.15\end{array}$} & \multirow{2}{*}{$\begin{array}{l}\text { P(bar) } \\
1.013\end{array}$} & \multirow{2}{*}{$\begin{array}{l}\mathbf{h}_{\mathbf{s}}(\mathbf{k J} / \mathbf{k g}) \\
16.736\end{array}$} & \multicolumn{3}{|c|}{$s_{s}(\mathrm{~kJ} / \mathrm{kg} \mathrm{K}) \mathbf{h}_{\mathrm{w}}(\mathrm{kJ} / \mathrm{kg}) s_{\mathrm{w}}(\mathrm{kJ} / \mathrm{kg} . K)$} \\
\hline & & & & 0.05913 & 83.99 & 0.296 \\
\hline 1 & 293.15 & 3.9 & 16.736 & 0.05913 & 84.26 & 0.296 \\
\hline 2 & 300.66 & 3.19 & 23.020 & 0.08030 & 115.58 & 0.402 \\
\hline 3 & 300.66 & 3.19 & 23.020 & 0.08030 & 115.58 & 0.402 \\
\hline 4 & 299.25 & 1.047 & 21.840 & 0.07637 & 109.49 & 0.382 \\
\hline 5 & 300.45 & 1.047 & 22.844 & 0.07972 & 114.51 & 0.399 \\
\hline 6 & 300.45 & 1.047 & 22.844 & 0.07972 & 114.51 & 0.399 \\
\hline 7 & 300.45 & 6.1 & 22.844 & 0.07972 & 114.97 & 0.399 \\
\hline 8 & 348.55 & 2.83 & 63.095 & 0.20404 & 315.83 & 1.020 \\
\hline 9 & 356.15 & 2.61 & 69.454 & 0.22210 & 347.7 & 1.11 \\
\hline 10 & 368.15 & 4 & 79.496 & 0.24984 & 398.33 & 1.249 \\
\hline 11 & 361.15 & 4 & 73.638 & 0.23377 & 368.89 & 1.169 \\
\hline 12 & 299.25 & 3.3 & 21.840 & 0.07637 & 109.7 & 0.382 \\
\hline 13 & 300.45 & 1.8 & 22.844 & 0.07972 & 114.57 & 0.399 \\
\hline 14 & 293.15 & 1.013 & 16.736 & 0.05913 & 83.99 & 0.296 \\
\hline 15 & 293.15 & 1.013 & 16.736 & 0.05913 & 83.99 & 0.296 \\
\hline 16 & 293.15 & 1.013 & 16.736 & 0.05913 & 83.99 & 0.296 \\
\hline
\end{tabular}

$$
s_{s}=s_{s 0}+C p_{s} \cdot \ln \left(T / T_{0}\right)
$$

The thermodynamic properties for different states throughout the unit are summarized in Tables 1 and 2 for the energy and exergy analyses.

Table 1. Specific enthalpy and entropy of salt and water

The minimum work input required for partial separation, at the same temperature, of $66.38 \mathrm{~kg} / \mathrm{s}$ of seawater into 5.78 $\mathrm{kg} / \mathrm{s}$ of distillate and $8.61 \mathrm{~kg} / \mathrm{s}$ of outgoing brine, is given by the difference of the minimum separation works/power of exiting and incoming streams, i.e.:

$$
W_{\min }=E x_{\min }=E x(\text { out })-E x(\text { in })
$$

One can note the exergyflowrates negative values of 5,6,7,13 and 14 states. Kahraman and al. [N. Kahraman and al.2005] give a comprehensive explanation of these singular values by the fact that the exergy due to concentration is different from zero at the dead state temperature and pressure.

Table 3 summarizes the exergy creation and destruction in the main components as well as the minimum work. The exergy efficiency is then computed from the ratio of the minimum work:

$$
\eta_{\mathrm{ex}}=\mathrm{Ex}_{\min } / \mathrm{Ex}_{\mathrm{tot}}
$$


Table 2. Enthalpy, entropy and exergyflowrates of salt and water mixture

\begin{tabular}{|c|c|c|c|c|c|c|c|}
\hline States & $\mathbf{P}($ bar $)$ & $\mathbf{T}(\mathbf{K})$ & Sal g/l & $m(\mathrm{~kg} / \mathrm{s})$ & $h(\mathrm{~kW})$ & $s(\mathrm{~kW} / \mathrm{K})$ & $\operatorname{Ex}(\mathrm{kW})$ \\
\hline 0 & 1.000 & 293.0 & 39.4 & 66.38 & 5399.36 & 21.44 & 0.00 \\
\hline 1 & 3.900 & 293.0 & 39.4 & 66.38 & 5416.57 & 21.44 & 16.59 \\
\hline 2 & 3.190 & 300.5 & 39.4 & 66.38 & 7430.58 & 28.41 & 25.17 \\
\hline 3 & 3.190 & 300.5 & 39.4 & 14.44 & 1617.28 & 6.18 & 5.47 \\
\hline 4 & 1.034 & 299.1 & 00.0 & 5.78 & 632.85 & 2.2 & 62.73 \\
\hline 5 & 1.034 & 300.3 & 65.3 & 8.61 & 934.31 & 3.76 & -53.8 \\
\hline 6 & 1.034 & 300.3 & 65.3 & 66.38 & 7203.19 & 29.00 & -414.81 \\
\hline 7 & 6.100 & 300.3 & 60.0 & 66.38 & 7232.36 & 29.00 & -385.60 \\
\hline 8 & 2.830 & 348.4 & 60.0 & 66.38 & 19886.01 & 69.49 & 397.57 \\
\hline 9 & 2.610 & 356.0 & 60.0 & 66.38 & 21890.52 & 75.4 & 670.37 \\
\hline 10 & 4.000 & 368.0 & 00.0 & 75.00 & 29868.75 & 93.67 & 3408.98 \\
\hline 11 & 4.000 & 361.0 & 00.0 & 75.00 & 27660.75 & 87.67 & 2959.88 \\
\hline 12 & 3.300 & 299.1 & 00.0 & 5.78 & 634.06 & 2.2 & 63.95 \\
\hline 13 & 1.800 & 300.3 & 65.3 & 8.61 & 934.87 & 3.76 & -53.20 \\
\hline 14 & 1.013 & 293.0 & 65.3 & 8.61 & 685.34 & 2.81 & -47.87 \\
\hline 15 & 1.013 & 293.0 & 00.0 & 5.78 & 493.02 & 1.71 & 67.17 \\
\hline$\underline{16}$ & $\underline{1.013}$ & $\underline{293.0}$ & $\underline{39.4}$ & $\underline{51.94}$ & $\underline{4224.80}$ & $\underline{16.77}$ & $\underline{0.00}$ \\
\hline
\end{tabular}

Table 3. Exergy creation and destruction in the main components

\begin{tabular}{|c|c|c|c|}
\hline & Component & Equation & $E x(k W)$ \\
\hline \multirow[t]{6}{*}{ Creation } & Seawater intake pump & $E x_{p}=E x_{1}-E x_{0}$ & 16.59 \\
\hline & Recirculation pump & $E x_{p}=E x_{7}-E x_{6}$ & 29.21 \\
\hline & Brine pump & $E x_{p}=E x_{13}-E x_{5}$ & 0.6 \\
\hline & Distillate pump & $E x_{p}=E x_{12}-E x_{4}$ & 1.22 \\
\hline & Reheater & $\mathrm{Ex}_{\mathrm{r}}=\mathrm{Ex}_{9}-\mathrm{Ex}_{8}$ & 272.8 \\
\hline & totalexergy creation & & 566.65 \\
\hline \multirow[t]{10}{*}{ Destruction } & Seawater intake pump & $E x_{d, p}=E x_{e_{l e}-} E x_{p}$ & 28.21 \\
\hline & Recirculation pump & $E x_{d, p}=E x_{e_{l e}}-E x_{p}$ & 36.59 \\
\hline & Brine pump & $E x_{d, p}=E x_{e l e}-E x_{p}$ & 2.15 \\
\hline & Distillate pump & $E x_{d, p}=E x_{e l e}-E x_{p}$ & 2.98 \\
\hline & Reheater & $E x_{d, r}=\left(E x_{8}+E x_{10}\right)-\left(E x_{9}+E x_{11}\right)$ & 176.3 \\
\hline & Waste seawater & $E x_{d, \text { charge }}=E_{2}-\left(E x_{3}+E x_{16}\right)$ & 19.7 \\
\hline & Distillat & $\mathrm{Ex}_{\text {distillat }}=\mathrm{Ex}_{12}-\mathrm{Ex}_{15}$ & 3.22 \\
\hline & Waste brine & $E x_{d, B r i n e}=E x_{13}-E x_{14}$ & 5.33 \\
\hline & Flashing stages & & 289.97 \\
\hline & Total exergy destruction & & 564.45 \\
\hline Minimum work & & $\mathrm{W}_{\min }=\mathrm{Ex}_{14}+\mathrm{Ex}_{15}-\mathrm{Ex}_{0}$ & 19.3 \\
\hline
\end{tabular}




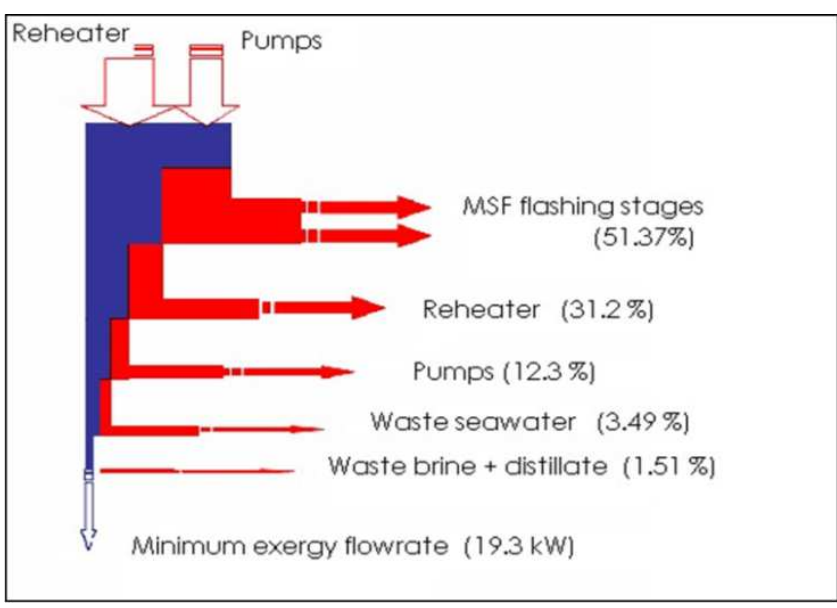

Fig. 2: The MSF plant exergy destruction fractions and exergy flow diagram

The exergy efficiency of the MSF plant is around 3.4\% computed from (10) while the exergy destruction fractions values are summarized in Fig. 4. Performances improvement could be obtained by increasing flashing stages and/or integration of the MSF process to the power plant by suppressing the combustor and feeding the MSF process directly from the power plant high pressure turbine. We should complete the thermodynamic investigation with the life cycle analysis in order to optimize the plant and also foresee a competitive integration to a steam cycle conventional power plant.

\section{Measurement of Seawater Temperature, pH, Salinity, Conductivity vs. Time}

Samples were collected from three sites: brine discharge point, the reject channel and the seawater intake of Cap Djinet power/MSF desalination plant.

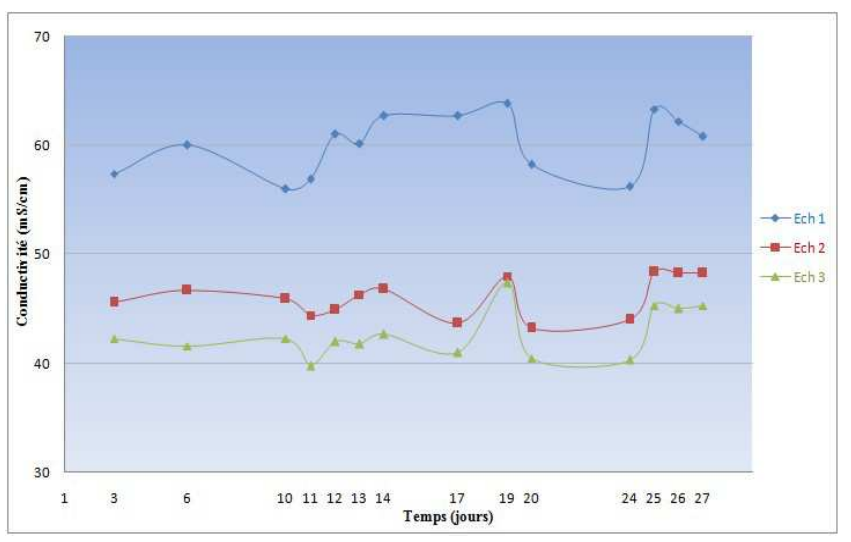

Fig.3: Seawater Conductivity

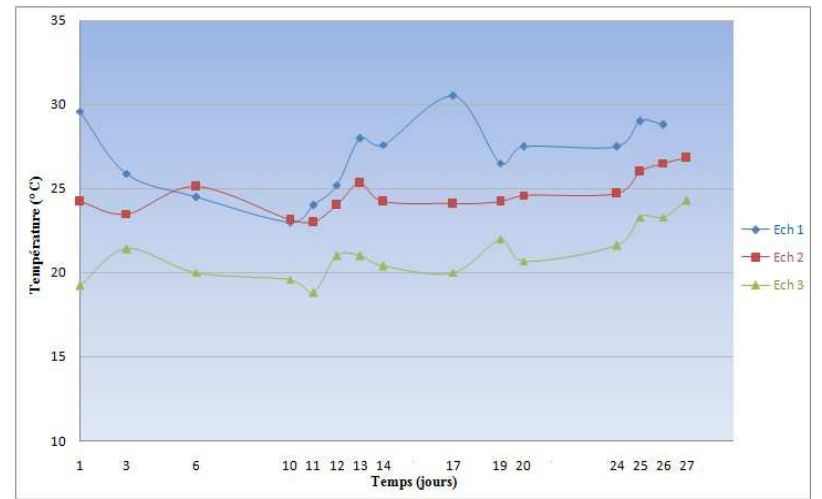

Fig.4: Seawater Temperature

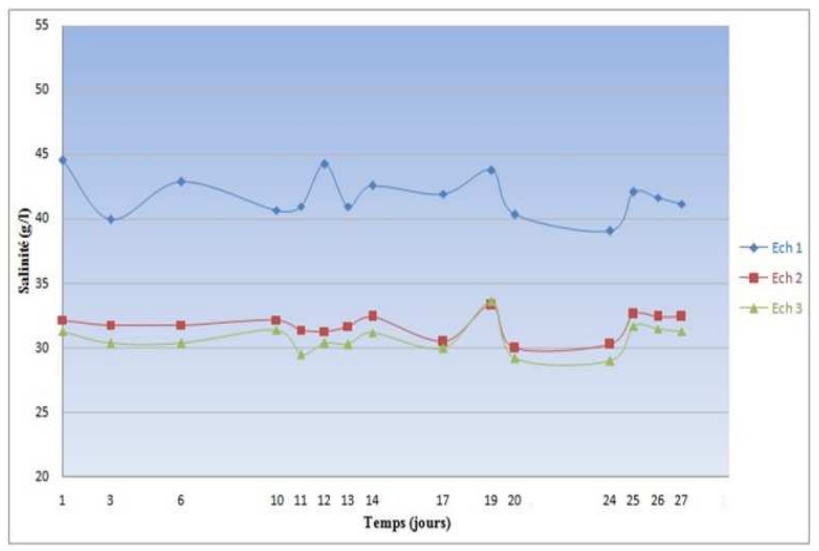

Fig. 5: seawater salinity distribution

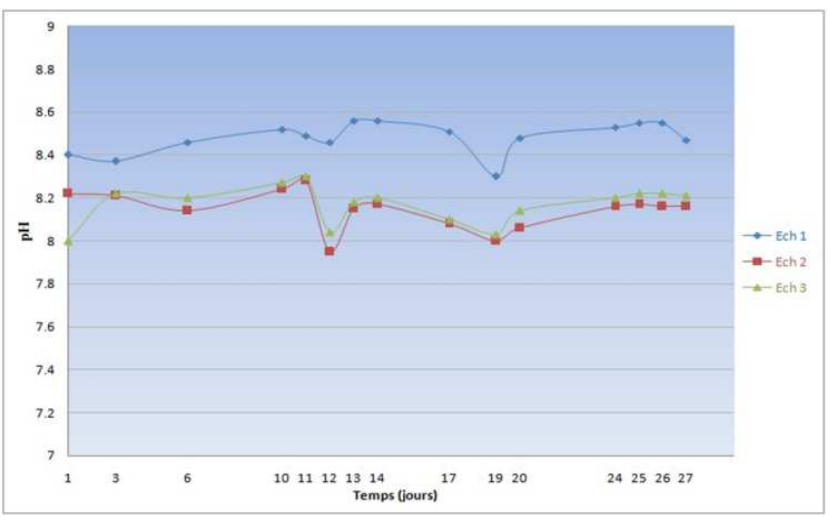

Fig. 6: Seawater $p H$ distribution

\section{Numerical Simulation of the Thermal Plume}

The numerical simulation of Cape-Djinet plant brine reject flow has been done for winter and summer weather conditions. The results show that the thermal plume of the brine reject diffusion process is concerning $500 \mathrm{~m}^{2}$ area with a 3 to $5^{\circ} \mathrm{C}$ temperature variation. 


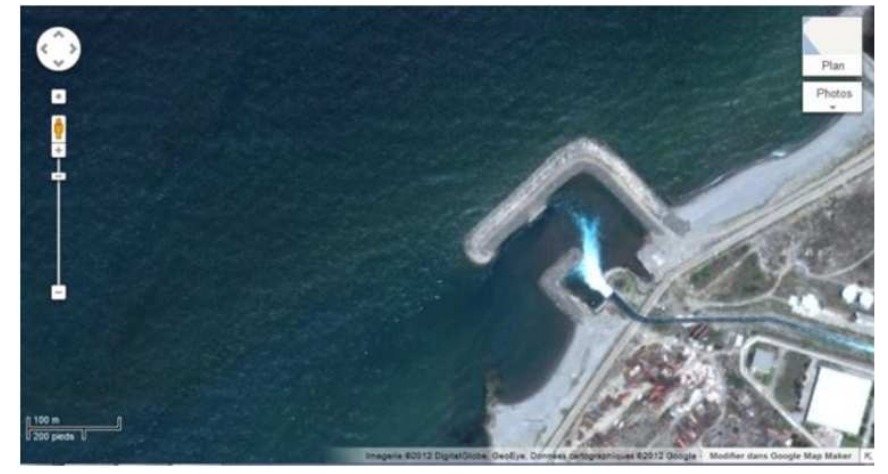

Fig. 7: Cape Djinet brine reject channel (Google earth)

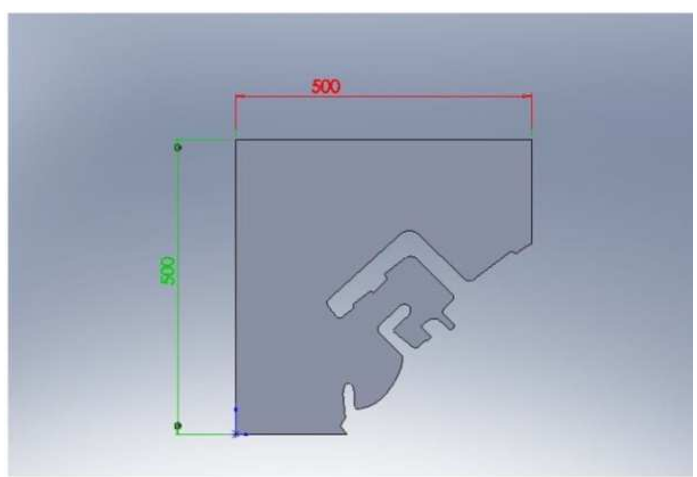

Fig. 8: Cape Djinet rejection domain
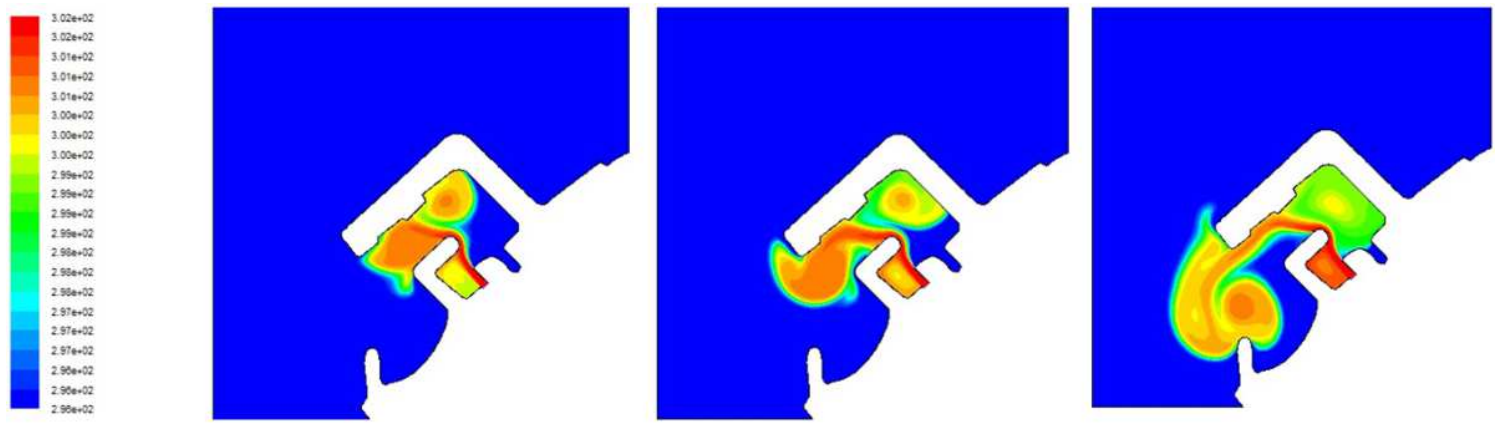

Fig. 10: Temperature distribution evolution at $t=500 \mathrm{~s}, t=720 \mathrm{~s}, t=1200 \mathrm{~s}$

From the numerical simulation results, we can observe that the flow does not reach the stationary regime. The temperature values are higher in the reject pool with a value of $\Delta \mathrm{Tmax}=5^{\circ} \mathrm{C}$, While the thermal spot runs away from the shore with a distance more than $500 \mathrm{~m}$ but with a temperature less than $\Delta \mathrm{T} \max \mathrm{T}=3^{\circ} \mathrm{C}$.
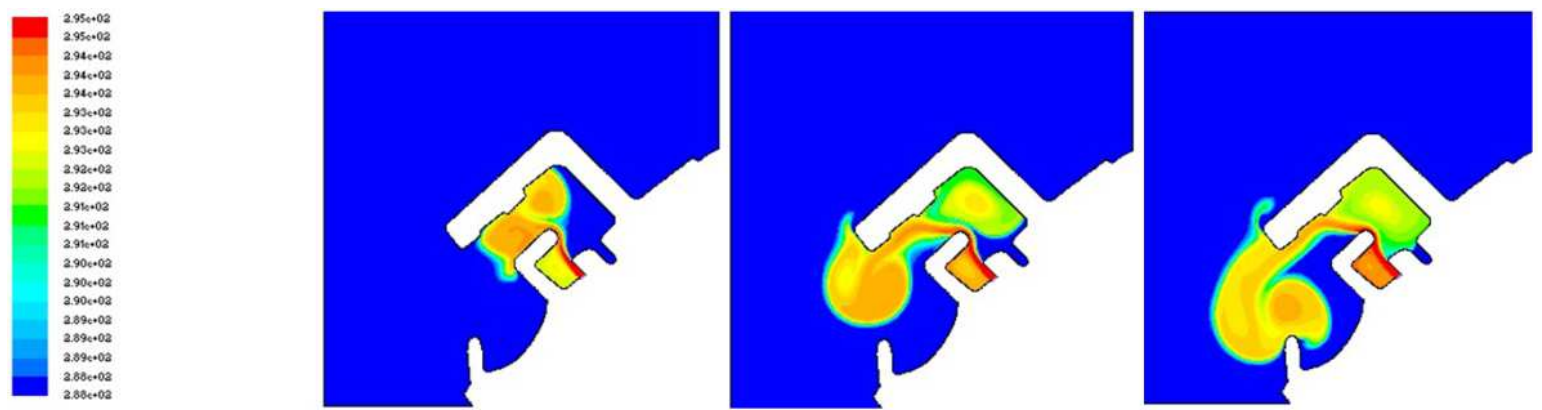

Fig. 11: Temperature distribution evolution at $t=442 \mathrm{~s}, t=925 \mathrm{~s}, t=1259 \mathrm{~s}$
For this second case, the initial temperature of the whole domain is $15^{\circ} \mathrm{C}$, while the inlet conditions are such that velocity is $1.8 \mathrm{~m} / \mathrm{s}$ for a temperature of $23^{\circ} \mathrm{C}$. 
The numerical simulation results show again that we do not reach the stationnary regime with a temperature difference of $\Delta \mathrm{T}_{\max }=7^{\circ} \mathrm{C}$ in the rejecting basin. The evolution of the flow shows the same observations we already reported in the winter case.

\section{Conclusion}

This paper focused on the marine environmental impacts in the Mediterranean arising from seawater desalination plants in Algeria. We presented a case study on brine rejection of Cape Djinet/MSF (Algeria) seawater desalination/power plant including exergy performances computation. The environmental impacts are mainly due to brine discharge but also to a lesser degree to the chemicals used in the cleaning of various modules, thermal pollution, etc.. We performed the measurement of four parameters (temperature, $\mathrm{pH}$, salinity and conductivity) and a numerical simulation to visualize the effects of rejection. Measurements of temperature and $\mathrm{pH}$ are compliant Algerian liquid discharges indicated in the legislative knowing that there are no limits imposed on the conductivity and salinity [JO RADP 2006]. Global results show no impact while there is a local impact due to the relatively small size of the Cap Djinet desalination plant $\left(4 \times 500 \mathrm{~m}^{3} /\right.$ day). The exergy analysis results showed that the MSF desalination unit is the key component where most irreversibilities and available energy destruction are occurring $\left(\mathrm{CO}_{2}\right.$ emissions too).

We propose to extend this study to the Hama desalination reverse osmosis $200,000 \mathrm{~m}^{3} /$ day plant (Algiers), then to all Algerian coast desalination plants $(1600 \mathrm{~km})$ and initiate an environmental impact assessment initiative across the western Mediterranean basin.

\section{Notations}

$\begin{array}{lll}\text { Cp: } & \text { specific heat } & (\mathrm{kJ} / \mathrm{kg} \mathrm{K}) \\ \text { Ex: } & \text { exergy } & (\mathrm{kJ}) \\ E x & \text { rate of exergy flow } & (\mathrm{kW}) \\ \mathrm{H}: & \text { enthalpy } & (\mathrm{kJ}) \\ \mathrm{h}: & \text { specific enthalpy } & (\mathrm{kJ} / \mathrm{kg}) \\ m: & \text { mass flowrate } & (\mathrm{kg} / \mathrm{s}) \\ \mathrm{m} f: & \text { mass fraction } & - \\ \mathrm{p}: & \text { pressure } & (\mathrm{bars}) \\ \mathrm{Q}: & \text { heat } & (\mathrm{kJ}) \\ \mathrm{S}: & \text { entropy } & (\mathrm{kJ} / \mathrm{K}) \\ \mathrm{Sal}: & \text { salinity } & (\mathrm{g} / \mathrm{l}) \\ \mathrm{T}: & \text { temperature } & (\mathrm{K}) \\ W: & \text { power } & (\mathrm{kW})\end{array}$

\section{Acronyms}

$\begin{array}{ll}\text { MSF: } & \text { Multi-Stage Flash } \\ \text { RO: } & \text { Reverse Osmosis } \\ \text { MVC: } & \text { Mecha.VaporCompress. }\end{array}$

\section{Subscripts}

$\begin{array}{ll}\text { crea: } & \text { Creation } \\ \mathrm{d}: & \text { destruction } \\ \text { ele: } & \text { electric motor } \\ \text { w: } & \text { water } \\ \text { ex: } & \text { exergy } \\ \mathrm{i}: & \text { state } \\ \text { in: } & \text { incoming } \\ \text { j: } & \text { heat source } \\ \text { m: } & \text { brine } \\ \text { min: } & \text { minimum } \\ \text { out: } & \text { exiting } \\ \text { p: } & \text { pump } \\ \text { r: } & \text { reheater } \\ \text { s: } & \text { salt } \\ \text { tot: } & \text { total } \\ 00: 00 & \text { ambient conditions }\end{array}$

\section{References}

[1] D. Boudieb, K. Mohammedi,A. Sadi,Y. Smaili," Analysis and optimization of a small scale bwro desalination plant integrating renewable energy", International Conference on Nuclear \& Renewable Energy Resources, Istanbul, Turkey, 20-23 May 2012

[2] K. Mohammedi, , J. Rheinländer, A. Sadi - Exergetic Analysis and Simulation under RESYSproDESALEnvironnment of an MSF Desalination Unit Performance.CMTDE 2008, Hammamet (Tunisia), april 2008.

[3] C. Santana, J. Jaime Sadhwani and Jose M. Veza : Case studies on environmental impact of seawater desalination. Desalination 185 (2005) 1-8

[4] S. Latteman , Development of an environmental impact assessment and decision support system for seawater desalination plants, $\mathrm{PhD}$ thesis ISBN $9780415583268, \mathrm{CRC}$ Press/Balkema, 2010.

[5] Y. Tamim, Environmental Issues of Desalination Universities Council On Water Resources Journal Of Contemporary Water Research \& Education Issue 132, Pages 11-18, December 2005

[6] S. Lattemann, T. H*opner. Seawater desalination.Impacts of brine and chemical discharges on the marine environment. Balaban Desalination Publications, L'Aquila, 2003. 
[7] V. M. Sedivy, Salt Partners are advising on salt production from seawater desalination reject Salt Partners Ltd.

[8] www.salt-partners.com

[9] S. Latteman,ThomasHöpnerEnvironmental impact and impact assessment of seawater desalination.Conference on Desalination and the Environment. Sponsored by the European Desalination Society and Center for Research and Technology Hellas (CERTH), Sani Resort, Halkidiki, Greece, April 22-25, 2007.

[10] I.S. Al-Mutaz,Environmental Impact of Seawater Desalination Plants Common Fundamentals And Unit Operations In Thermal Desalination Systems - Vol. Iii Environmental Impact Of Seawater Desalination Plants

[11] (C) Encyclopedia of Desalination and Water Resources (DESWARE) 2012.

[12] J.O RADP, Décret Exécutif n ${ }^{\circ} 06-141$ du 20 Rabie El Aouel 1427 correspondant au 19 Avril $2006 \mathrm{du}$

[13] Journal Officiel de la République Algérienne réglementant les rejets d'effluents liquides.

[14] J.O RADP, Décret exécutif №93-160 du 10 Juillet 1993, du Journal Officiel de la République Algérienne réglementant les rejets d'effluents liquides.

[15] H.H. Al Barwani, Anton Purnama - Evaluating the Effect of Producing Desalinated Seawater on Hypersaline Arabian Gulf .European Journal of Scientific Research ISSN 1450216X Vol.22 No.2 (2008), pp.279-285

[16] N. Boutarfa - Contribution of power to water production the case of Algeria $-19^{\text {th }}$ World Energy Congress, Sydney, Australia September 5-9, 2004

[17] A. Sadi - Seawater desalination share among water and market policy changes in Algeria. Desalination Vol. 165 (2004) pp. 99-104.

[18] G. Bravo, Trends of Desalination Bids for RO plants in North Africa: The Case of Algeria, EuroMed 2004 conference on Desalination Strategies in South Mediterranean Countries, Marrakech, Morocco, 30 May-2 June, (2004).

[19] HouShaobo, Zhongjing Zhang, Zhongzhou Huang, AixiaXie -Performance Optimization of Solar Multi-stage flash desalination Process using Pinch Technology. Desalination Vol. 220, (2008) pp.524-530.

[20] K. Mohammedi, A. Bouziane;.-Small Scale Water Desalination Powered by Autonomous Smart Hybrid Systems Integrating Renewable Energy. $4^{\text {th }}$ Arab Cleaner Production Workshop, Amman (Jordanie) 8-10 Mars 2010.
[21] M.S. Tanvir, I.M. Mujtaba - Optimisation of Design and Operation of MSF Desalination Process using MINLP Technique in gPROMS. Desalination Vol. 222, (2008) pp. 419-430.

[22] A.S. Nafey, H.E.S. Fath, A.A. Mabrouk-Exergy and Thermoeconomic Evaluation of MSF Process using a new Visual Package. Desalination Vol. 201, (2006) pp. 224-240.

[23] A.A. Mabrouk,A.S. Nafey, H.E.S. Fath,-- Analysis of a new design of a multi-stage flash-mechanical vapor compression desalination process. Desalination Vol. 204, (2007) pp. 482500 .

[24] H.E.S. Fath, M.A. Ismail - An Online Clearing System to Reduce Demister Fouling in MSF SidiKrir Desalination Plant 2x5000 $\mathrm{m}^{3} /$ day. Desalination Vol. 220, (2008) pp. 252-257.

[25] N. Scenna, S. Mussati - MSF Design taken into account availability. Desalination Vol. 222, (2008) pp. 673-681.

[26] A. Sung Joon, L. Chang Jun, Yunju Jung, Chonghun Han, Y. En Sup, Giback Lee - Fault diagnosis of the MSF process based on signed digraph and dynamic partial least square. Desalination Vol. 228, (2008) pp. 68-83.

[27] G. Cali, E. Fois, A. Lallai, G. Mura - Optimal Design of a Hybrid RO/MSF Desalination system in a non-OPEC country. Desalination Vol. 222, (2008) pp. 673-681.

[28] J. Rheinländer, E. Perz, O. Goebel, Performance simulation of integrated water and power systems - software tools IPSEpro and RESYSpro for technical, economic and ecological analysis, European Conference on Desalination and Environment: Fresh Water for All, Malta, 4-8 May (2003).

[29] E. Perz, S. Bergmann, A simulation environment for the techno-economic performance prediction of water and power cogeneration systems using renewable and fossil energy sources, EuroMed 2006, Desalination Strategies in South Mediterranean Countries, Montpellier-France, 21-25 May, (2006).

[30] Y. Cerci, YunusCengel, Byard Wood, NafizKahraman, and E. Sinan Karakas Improving the Thermodynamics and Economic Efficiencies of Desalination Plants Minimum Work Required for Desalination and Case Studies of Working Plants Agreement No. 99-FC-81-0183. Desalination and Water Purification Research and Development Program Final Report No. 78 University of Nevada Reno, Nevada November (2003)

[31] N. Kahraman, YunusA.Cengel - Exergy analysis of a MSF Desalination Plant. Energy Conversion and Management Vol. 46, (2005) pp. 2625-2636. 